\title{
THE IMPACT OF CRISES \\ ON THE POSITION OF THE SENATORIAL ELITE
}

The crises of the third century altered the position of the senatorial order. This development has been discussed by many scholars, some of whom have even argued that senators had to deal with a crisis within the social system and entirely lost their position as leading elite to the ordo equester. ${ }^{1}$ More recently, scholars have taken a less extreme position, but they have still been inclined to focus on the changes in the situation of the ordo senatorius in the third century, and to ignore, or at least deemphasize, the continuities. ${ }^{2}$ However, the fact that certain offices held by senators at the end of the second century $\mathrm{AD}$, remained in their hands after the reforms of Diocletian, shows some continuity. Even though if anything it was the equestrian order that amassed positions of power at the expense of the senatorial order over the course of the third century (see Chapter 3 below), it was also the equestrian order that eventually disappeared in the late Roman Empire. ${ }^{3}$ Thus, before further inquiry into changes in the administration and social hierarchies, it seems constructive to observe and map out the continuity which (at least part of) the senatorial order ensured during the chaos and transformations of the third century.

The starting point in seeking continuity is to determine a number of high positions which remained reserved principally for senators both at

${ }^{1}$ E.g. Alföldy (1988), 193: 'The history of the imperial Roman elite during the crisis of the third century seemed to be leading to a conclusion whereby the senatorial order totally lost its leading position to the equestrian order.' Cf. id. (1988), 121-122; Stein (1963), 445; Rémondon (1970), 100-101; on the changing role of the senate after AD 180, see also Talbert (1984), 490-491.

${ }^{2}$ For more recent views on the ordo senatorius in the third century, see, for instance, Potter (2004) passim; Lo Cascio (2005), 136. In generic overviews, however, the traditional view still prevails. See, for instance, Sommer (2004), 24: 'Der Senatorenstand hatte endgültig als wichtigste der drei tragenden Säulen des Prinzipats ausgespielt und wurde immer mehr an den Rand gedrängt.'

${ }^{3}$ On this, see Alföldy (1988), 193-194. The equestrian order was not formally abolished, but highly placed equites were enrolled into the senatorial order and the lower equestrian positions went to public officials and officers of lower rank. 
the end of the second century and after Diocletian's reforms, which will generate a list of the men who are known to have held these offices in the period under discussion. A subsequent prosopographical examination of these office holders will allow us to distinguish a nucleus within the senatorial elite; this nucleus proved able to maintain or even develop its position within the third century.

\subsection{Establishing the Senatorial Elite in the Third Century}

As has been noted in the Introduction, the senatorial order (ordo senatorius) was a heterogeneous group which consisted of several strata (see Figure 2.1).

Figure 2.1. Schematic overview of strata within the senatorial order

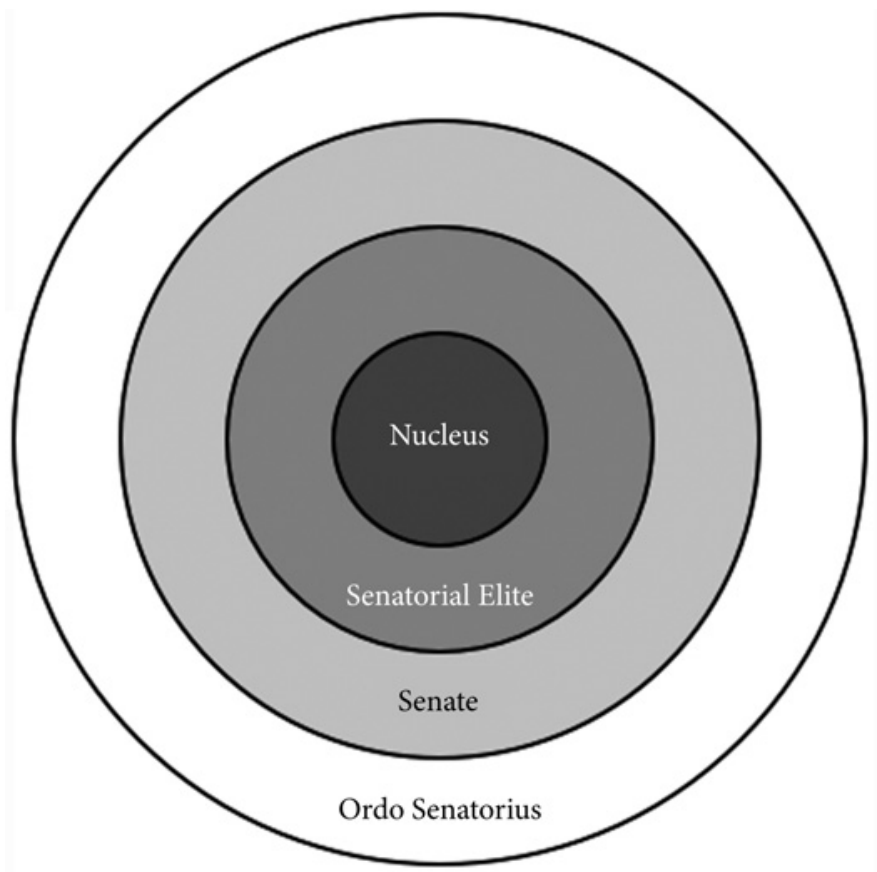

Senatorial nucleus Inner circle of the senatorial elite

Senatorial elite All members of the senate of consular rank Senate Active members of the senate in Rome

Ordo senatorius Everyone belonging to the senatorial order 
A sharp distinction held between mere members of the order and full active members of the senate, who held senatorial office(s) in Rome and elsewhere in the emperor's service. Entry into the senate during the Principate was normally restricted to twenty men who were annually elected as quaestors. In addition, men could be taken into the senate from the equestrian order through co-option (adlectio) by emperors. Emperors (Vespasianus, Marcus Aurelius and Septimius Severus) used this occasionally to replenish the senate. ${ }^{4}$ Only a minority of senate members succeeded in attaining a consulship. These men of consular rank constituted what is called 'the senatorial elite' in this study. These senators had gone through a considerable part of the senatorial cursus honorum and their backgrounds and careers are (relatively) well-documented.

High consular offices which continued to exist after the reforms of Diocletian were the (ordinary) consulate, the city prefecture of Rome, and the governorships of the provinces of Africa Proconsularis and Asia. It was in these posts that the power and status of the third-century senatorial elite manifested itself most clearly. Therefore these offices are a suitable focus for an analysis of continuity within the senatorial elite's position. The holders of these four offices are documented relatively well and are discussed in detail in several scholarly works. ${ }^{5} \mathrm{~A}$ list of holders of these offices can be found in Appendix $2 .^{6}$

${ }^{4}$ Cf. Hopkins and Burton in Hopkins (1983), 146, who stress that this 'was not a major method of normal recruitment'. Such homines novi thus immediately entered the senate and, in case of adlectio inter consulares, they instantly penetrated the senatorial elite. A well-known example of an eques who entered the senate through adlectio and then had a brilliant senatorial career is the emperor Pertinax (see Thomasson (1996), 73, no. 94, for a discussion of his career). From circa AD 250, such Pertinaces can no longer be detected in the available evidence.

${ }^{5}$ See, for instance, Degrassi (1952) for consular fasti; Barbieri (1952) on senators between AD 193 and 285; lists of consuls, city prefects, proconsules Africae and Asiae in PLRE I, 1041-1075; Thomasson (1972-1990), 205-242, on the governors of Asia; Christol (1986), 97-136, on consuls and city prefects from 250 onward; Leunissen (1989) with lists of consuls, governors of Africa and Asia and city prefects between AD 180 and 235; Thomasson (1996) on governors of Africa, and the fasti in Johne-GerhardtHartmann (2008), vol. 2, 1063-1189.

${ }^{6}$ Only ordinary consulates (consulatus ordinarii) are included in this list, since their number is fixed at two per year, and the names of all the consules ordinarii are known to us including the dates of their consulates. Suffect consulships and their dates can usually only be deduced from the fact that a senator held a consular position, and there is no way to establish the number of consules suffecti between AD 193 and 284 . Cf. Mommsen (1887), vol. 2, 84, on suffect consuls: 'The number of [suffect] pairs and the period for which they held office were extraordinarily unequal, and the latter hardly 
Several nomina (gentilicia) recur on the list regularly. A closer examination shows that in quite a few cases it is plausible that men with similar names belonged to the same gens, or at least claimed dynastic connections with an aristocratic family. Admittedly, to trace actual kinship at the evidence of nomenclature is to thread on thin ice. ${ }^{7}$ Since late antique Romans seem at times to have fabricated connections with illustrious senatorial ancestors to impress contemporaries, we must stay aware that third-century Romans may have adopted this strategy as well. After all, 'membership of a multi-generational family was an important component of Roman aristocratic identity. ${ }^{8}$ Ammianus Marcellinus even made fun of those senators who gave themselves famous names. ${ }^{9}$ Epigraphic evidence in which actual kinship is confirmed is rare, let alone cases in which the nature of the relationship is named. ${ }^{10}$ Only in a very small number of cases can the epigraphic material be complemented by evidence from literary or legal sources. Therefore nomenclature often is our only indication for potential kinship between senators. Here, however,

ever seems to have been regularized [...].' ('Die Zahl der Paare und die Fristen sind ausserordentlich ungleich und eine formelle Regulierung der letzteren scheint kaum je eingetreten zu sein [...]'). That is why consules suffecti are not included in the list. They are, however, taken into account in the analysis of senatorial elite families in the next section.

7 Salomies (1992) has shown once again that a firm set of rules for Roman polynomy-which item is adoptive, which represents the father's family, which the mother's, etc. - cannot be established.

${ }^{8}$ Hillner (2003), 130. According to Hillner (130 ff.), a senator could stress his genealogy simply by inventing memories of alleged ancestors' ownership of his house. While senatorial residences were conceived as symbols of lineage, ancestors' genealogies were often fictitious. This practice demonstrates how powerful claims of illustrious ancestry was in Late Antiquity. Septimius Severus' retrospective adoption into the Antonine dynasty (Dio 77, 9, 4; cf. HA, Vita Sev. 10, 6; Aurelius Victor, Liber de Caesaribus 20, 30; $B M C R E \mathrm{~V}, 136, \dagger)$ is a well-known third-century example of the strategy of inventing family relations. On this, see Birley (1988), 1; 117; 122, and Hekster (2002), 189-191, with further references.

9 Ammianus Marcellinus 28, 4, 7: Praenominum claritudine conspicui quidam (ut putant) in immensum semet extollunt, cum Reburri et Flavonii et Pagonii Gereonesque appellentur, ac Dalii cum Tarraciis et Ferasiis, aliisque ita decens sonantibus originum insignibus multis. ('Some men, distinguished (as they think) by famous fore-names, pride themselves beyond measure in being called Reburri, Flavonii, Pagonii, Gereones, and Dalii, along with Tarracii and Pherrasii and many other equally fine-sounding indications of eminent ancestry.')

${ }^{10}$ Hillner (2003), 132, puts it: 'Epigraphic evidence is generally limited to a number of inscriptions found in the same area recording different members of the same gens.' Although Hillner focuses on Late Antiquity in her article, these words also apply to the third-century evidence. 
the question as to whether there was actual consanguinity between senators is of minor importance. Even if the relationship was invented, or based on adoption, it reflected the significance of belonging to a certain aristocratic gens. Apparently, belonging to or claiming to belong to a certain gens could increase one's chances to obtain top positions within the senatorial cursus honorum, namely to become consul ordinarius, praefectus urbi, proconsul Africae or proconsul Asiae.

In order to sort out those gentes which certainly belonged to the senatorial elite during a considerable part of the third century, two criteria applied: (a) at least three members holding one or more of the selected consular positions should be known to us, and (b) these members' careers should stretch over a total of at least two decades. The following eighteen gentes emerge as traceable: (1) the Acilii (Glabriones et Aviolae), (2) the Anicii, (3) the Bruttii, (4) the Caesonii, (5) the Catii, (6) the Claudii Pompeiani, (7) the Claudii Severi, (8) the Egnatii, (9) the Fulvii Aemiliani, (10) the Hedii Lolliani, (11) the Marii, (12) the Nummii, (13) the Pollieni, (14) the Pomponii, (15) the Postumii, (16) the Valerii, (17) the Vettii, and (18) the Virii. ${ }^{11}$

Within the senatorial elite these families represent the percentages listed in Table 2.1. These indicate that members of these eighteen gentes held a substantial part of the examined offices between AD 193 and 284 . Further analysis shows that these positions were occupied by members of these families throughout the third century. That means that one can argue that, at least during the third century, these families were able to create and/or maintain their position within the senatorial elite. ${ }^{12}$ The

\footnotetext{
${ }^{11}$ Inevitably, applying these criteria excludes certain gentes which may have belonged to the third-century senatorial elite. For instance, the Ragonii: although more than three members of this gens are known to us, only two of them held a consulship between AD 193 and 284 (L. Ragonius Urinatus Tuscenius, suffectus ca. 210 and [L.] Ragonius Venustus, consul ordinarius 240). L. Ragonius Urinatius Larcius Quintianus was suffectus before 193, under Commodus, and L. Ragonius Quintianus was consul ordinarius in 289 (see Dietz (1980), 372, stemma 9). The same goes for the Aufidii from Pisaurum: Aufidius Fronto, consul ordinarius 199, and Aufidius Victorinus, consul ordinarius 200, were related, but it is unclear whether C. Aufidius Marcellus, proconsul Asiae 220/ 221; consul II ordinarius 226, also belonged to this gens. Moreover, I am aware that not only families of importance during the second century and the beginning of the third, but also gentes which became influential only at the end of the period under discussion have gone neglected. However, it must be kept in mind that the intention of this study is not to paint a complete picture of the entire third-century senatorial elite, but merely to point out continuity within this senatorial elite.

12 The position of these families in the first and second centuries AD is looked at in some more detail in the Prosopography below.
} 
following analysis will throw more light on the position of these families in the course of the third century.

Table 2.1. Representativeness of the selected families

\begin{tabular}{llll} 
& $\begin{array}{l}\text { Total number of } \\
\text { appointments known } \\
\text { to us }(\text { AD 193-284) }\end{array}$ & $\begin{array}{l}\text { Number of office } \\
\text { holders belonging to } \\
\text { selected families }\end{array}$ & Percentage \\
\hline Office & $131^{13}$ & $45-51^{14}$ & $34-39 \%$ \\
\hline Ordinary consuls & 44 & $11-12^{15}$ & $25-27 \%$ \\
City prefects & $12-14^{16}$ & $17-20 \%$ \\
Proconsuls Afr/Asia & 70 & 20
\end{tabular}

13 The total number of ordinary consuls between AD 193 and 284 was 184 ; in this table the 53 consulates ( $29 \%)$ filled by emperors and their prospective heirs are excluded. If they were included, the percentage of ordinary consuls would be lower (24-28\%), but would nonetheless remain relatively high.

14 The number of consules ordinarii per family: 3 Acillii; 3 Bruttii; 2 Catii; 4 Claudii Pompeiani; 2 Claudii Severi; 1 Egnatius; 3 Fulvii; 2 Hedii; 3 Marii; 4 Nummii; 1 Pollienus; 2 Pomponii; 1 Postumius; 6 Valerii; 4 Vettii; and 4 Virii. Perhaps some others might be added, but their connections to these eighteen senatorial elite families are less certain: M. Laelius (Fulvius?) Maximus Aemilianus, consul ordinarius 227, may have been distantly related to the Fulvii. Bassus, consul ordinarius 259, may have been identical with Pomponius Bassus [...] stus, but this cannot be determined with certainty. The other consul ordinarius of 259, Aemilianus, cannot be identified with certainty either. It has been suggested that he was either identical with M. Laelius (Fulvius?) Maximus Aemilianus, or with Fulvius Aemilianus, consul ordinarius 244, or Fulvius Aemilianus, consul ordinarius 249. On this, see Christol (1986), 100, note 19. The same goes for Aemilianus, consul ordinarius 276. Furthermore it is uncertain whether Nummius Faus(t)ianus, consul ordinarius 262, was a member of the gens Nummia, and it has been suggested that Paulinus, consul ordinarius 277, was related to the Anicii.

15 City prefects per family: 1 Caesonius; 1 (?) Claudius Severus; 1 Egnatius; 1 Marius; 1 Nummius appointed twice; 1 Pomponius; 2 Postumii; 1 Valerius; 2 Virii. On the doubtful cases: one member of the Claudii Severi, if the Severus mentioned in Cod. Iust. 4, 56, 2, was indeed identical with (Cn. Claudius?) Severus. On this, see Leunissen (1989), 176, note 211; one of the Fulvii Aemiliani may be added, if Groag's suggestion that Fulvius Gavius N[umisius ...] Aemilianus was city prefect in 249 was indeed right. See Dietz (1980), 165, with further references. For the moment, he has not been included in the count.

16 Proconsuls of Africa and/or Asia per family (men serving as agens vice proconsulis are not included in this count): 2 Anicii; 3 Caesonii; 1 Egnatius (three terms); 2 Hedii; 3 Marii; 1(?) Nummius; 1(?) Pollienus; 1 Valerius. On the doubtful cases: one of the Nummii, if the identification of Albinus with Nummius Umbrius Primus Senecio Albinus on $A E$ 1933, 258 is correct. See Leunissen (1989), 226, note 72 for further references; one Pollienus, if Pollienus Auspex maior indeed held his proconsulship between AD 193 and 200 (and not before 193). Several men may perhaps be added, but for the moment they are not included in the count. Those men are: an Acilius Glabrio was governor of Africa, but the date cannot be determined with certainty. It may have been M('?). Acilius Glabrio in the third century, after 256, but it may also have been another member of the gens in the second century. On this matter, see Thomasson (1996), 94, no. 132; furthermore, 


\subsection{Analyzing the Selected Families}

An indepth examination of these eighteen senatorial families will yield a clearer perception of the position of the members of these families, their careers, their backgrounds and origins, their social status, the relationships within the gentes and interrelations with other senatorial families.

Ideally, we could present a complete picture of these families and reconstruct their careers. The evidence, however, is too fragmentary. What we have is a number of inscriptions and, in some cases, literary or judicial sources mentioning these men, but only in very few cases does the evidence inform us of all the positions held by a person or of precise family connections. Often, the only indication for an individual's or family's geographical origin is the provenance of relevant inscriptions. Yet, fortunately there is one exception, one family of which a more or less complete picture can be painted: the gens Caesonia. The careers of three generations of this family's men can be reconstructed by means of several career inscriptions. Their careers coincide with Roman imperial history stretching from the reign of Marcus Aurelius until the reign of Diocletian. These careers, and the family's social position between AD 193 and 284, will serve as an illustrative example of continuity and will demonstrate the capacity of one family to even strengthen its position in the third century. Because the evidence is uniquely informative, the Caesonii may not be representative for all senatorial elite families. Yet they will form the starting point of my analysis, because their record, together with the more fragmentary information on the other families, can illustrate the position of the selected senatorial elite families throughout the third century and their role within imperial administration.

\section{The Caesonii-The Course of the Third Century Reflected in Three Careers}

Gaius Caesonius Macer Rufinianus, born around AD 155/160, was the first member of the gens Caesonia to hold a consulship. ${ }^{17}$ It is generally

another Pollienus may be added, if the suggestion in Eck (1983), 855, that Pollenius Armenius Peregrinus was proconsul Asiae is correct; and one Pomponius, if Pomponius Bassus [...] stus was indeed proconsul Africae or Asiae, as suggested by PLRE I, Bassus 17. For the moment, he has not been included in the count.

${ }^{17} P^{2} R^{2} \mathrm{C}$ 210. On this man and his career, see also Eck (1985), 76-77; Christol (1986), 160-162; Leunissen (1989), 388; Thomasson (1996), 86-87 no. 118; BadelBérenger (1998), 139-141. Caesonius was a Roman family name documented in the first century вC. See DNP, vol. 2, 929, s.v. Caesonius. 
assumed that he had Italic roots. ${ }^{18}$ Beside the fact that his father was also called Gaius, nothing is known about his ancestors. Dietz claims that this Caesonius must have been a homo novus based on the fact that he started his career as a triumvir capitalis. However, Eck rightly notes that this argument cannot be considered decisive. ${ }^{19}$ Caesonius Macer Rufinianus married Manilia Lucilla, and it has been suggested that she was the sister or daughter of (Tiberius) Manilius Fuscus, consul suffectus in 196/7, consul II ordinarius in $225 .{ }^{20}$ Caesonius' career can be outlined from an inscription on an epitaph set up by his son. This inscription found near Tibur mentions his entire career in inversed order. ${ }^{21}$

The start of Caesonius' senatorial career was not exceptional. Being one of the vigintiviri, he fulfilled a police-function in Rome as triumvir capitalis. This appointment cannot be dated precisely, but was probably at the end of the reign of Marcus Aurelius, just before Caesonius took his position as military tribunus, one of the members of staff of legio I Adiutrix. For this position Caesonius left Italy to go to Brigetio in Pannonia Superior, probably during Marcus' second expedition in Germania. ${ }^{22}$ Caesonius was about twenty years old at that time. It was while he held this function that the emperor granted his unit military honors (dona militaria), which is proudly mentioned in the inscription as well. The next step in his cursus honorum was a position as quaestor in Narbonensis after which he returned to Rome to become tribunus plebis, probably already under Commodus. About 185 , he was sent to Hispania Baetica as legatus to assist the governor, and about two years later he became praetor and entered the next stage of his career.

Before reaching the consulship, his praetorian career included six or seven positions and can, therefore, be considered rather long. He assisted

${ }^{18}$ Eck (1985), 76, and Leunissen (1989), 357, suggest that he was from Regio I, possibly from Antium. However, according to Jacques (1986), 168, the existence of several gentilic attestations from Italy was due to normal investments of an important senatorial family and does not indicate their geographical origin.

${ }_{19}$ Dietz (1980), 104 f.; Eck (1985), 76.

20 L. Caesonius Lucillus Macer Rufinianus, the son of Caesonius and Manilia Lucilla, was one of the Fratres Arvales, which was an inherited priestly office. That is why Settipani suggests that Lucilla may have been connected to Ti. Manilius Fuscus $\left(P I R^{2} \mathrm{M} 137\right)$, who was Frater Arvalis in 190. See Settipani (2000), 349, note 4.

${ }^{21}$ CIL $14.3900=I L S 1182=$ Inscr. It. IV 1, 102 (Latium, Tibur). For an overview of his career and the careers of the other Caesonii, see the Prosopography at the end of this chapter.

${ }^{22}$ Alföldy (1969), 146-147; Syme (1971), 159, contra Pflaum (1978), 84-85, who suggested that this office was held in 173 . 
the governor of Asia as legatus and subsequently held the first of several positions as Italic curator in his career. As curator rei publicae he probably executed a financial task in Asculum (Picenum), followed by another military function as legatus of legio VII Claudia at Viminacium in Moesia Superior. Next, he became proconsul of Achaia. Governing Greece was reserved for junior praetorian senators. After his proconsulship Caesonius returned to Italy to become curator rei publicae of Tarracina, a city in Latium, at the end of the reign of Commodus or not long after this emperor's death in $192 .{ }^{23} \mathrm{He}$ went to Spain for his next position as legatus Augusti pro praetore, governing Lusitania. It is not certain whether he had already been appointed when Septimius Severus was proclaimed emperor, or whether the new emperor appointed him, but he probably retained his position until he served as consul suffectus circa 197/198, when he was about forty years old. The consulship may have been a reward for taking part in putting down the rebellion of Lucius Novius Rufus, governor of Hispania Citerior and a supporter of Clodius Albinus, one of Severus' rivals. ${ }^{24}$ This certainly would explain the further course of his career.

Just before or not long after his consulship, Caesonius was appointed to his third term as a curator rei publicae, this time in Teanum, a city in the northern part of Campania. ${ }^{25}$ Around 198 he became responsible for the banks and channels of the Tiber as curator alvei Tiberis, a position which both his son and his grandson would occupy in the future. After this, probably around 200, Caesonius was appointed to his first consular governorship in Germania Superior. For his next post of curator aquarum et Miniciae he returned to Italy. Presumably he carried out this position sometime between 203 and 213, but the exact date and duration are unclear. ${ }^{26}$ Caesonius' next office crowned his career: he was appointed proconsul to govern the economically important province of Africa. He may have held this position under Caracalla in $213 / 214$ or $214 / 215$, but

${ }^{23}$ Leunissen (1989), 388, suggests circa 193. For a date at the end of the reign of Commodus, see Eck (1999), 236.

${ }^{24}$ Alföldy (1969), 146; Christol (1986), 161; Leunissen (1989), 155 and 289.

${ }^{25}$ Christol (1986), 161, agrees with $P I R^{2} \mathrm{C} 210$ that this position must have been held before the consulship and that the post of curator alvei Tiberis must have been Caesonius' first consular task. Leunissen (1989), 388, suggests that the curatorship of Teanum was his first consular position.

${ }^{26}$ Christol (1986), 161, note 9, follows Pflaum (1978), 85, who suggests 204 or not much later. Here Pflaum rectifies the date of about 220 , previously suggested by him. See Pflaum (1963), 234-237. 
a date under Elagabalus or Severus Alexander has also been suggested. ${ }^{27}$ Caesonius' task as curator rei publicae of Lavinium or Lanuvium, both of which are in Latium, brought him back to Italy once more. He held it twice, according to Eck at the end of the reign of Caracalla. ${ }^{28} \mathrm{He}$ was also sodalis Augustalis, but it is impossible to determine the exact chronological point of this priestly office within his career.

His career ended in a remarkable way: Caesonius Macer Rufinianus was comes of the emperor Severus Alexander, most probably during the latter's Persian campaign of AD 231-233. It seems unthinkable that the senator, who must have been over seventy years old during the Persian expedition, actually accompanied the emperor on this perilous and exhausting Eastern campaign. Suggestions that the title comes had developed into a title to indicate that someone was connected to the court, like amicus, might therefore very well be right. ${ }^{29}$

The son of Caesonius Macer Rufinianus and his wife Manilia Lucilla was named Lucius Caesonius Lucillus Macer Rufinianus and was probably born around $195 .{ }^{30}$ His career is known to us mainly from an inscription on a statue base also found near Tibur. ${ }^{31}$

He started his career as one of the vigintiviri with a judicial position as decemvir stlitibus iudicandis sometime at the beginning of the reign of Caracalla. At that time or not long afterwards, the family was accepted into the patriciate (electus in familiam patriciam). This can be seen in the career of Caesonius Lucillus Macer Rufinianus: he was appointed quaestor as imperial candidatus at the end of Caracalla's reign and became praetor candidatus after that, without any intervening offices, which was typical for a patrician career. His appointment as praetor came probably after the death of Caracalla under Elagabalus, around 220/222. ${ }^{32}$

27 Thomasson (1996), 86-87, suggests a date under Elagabalus or Severus Alexander and that, in this case, his son may have served as his father's legatus in Africa. He claims that there is not much space for a proconsulship during the reign of Caracalla. Christol (1986), 162, and Leunissen (1989), 388, suggest a date between 212/213 and 215.

${ }^{28}$ Eck (1985), 76, accepts Lavinium; Eck (1999), 234, accepts Lanuvium.

${ }^{29}$ Pflaum (1978), 85-86; see also Thomasson (1996), 87.

${ }^{30}$ Christol (1986), 162, note 15.

${ }^{31}$ CIL $14.3902=I L S 1186=$ Inscr. It. IV I, 104 (Tibur, Italy). See also: CIL $6.2104 \mathrm{~b}$ (Roma); CIL 6.37165 (Roma); $A E$ 1915, 102 = CIL 6.39443 (Roma). For this Caesonius, see PIR ${ }^{2}$ C 209 and Dietz (1980), 103 ff., no. 17; Christol (1986), 158-172; Leunissen (1989), 377; Thomasson (1996), 90, no. 122; Peachin (1996), 112-114.

32 Peachin (1996), 113, dates the first steps of his career somewhat earlier. He assumes that this Caesonius was quaestor in circa 212 and praetor in circa 217. In that case, both positions would have been carried out during the reign of Caracalla. 
Like his father, Caesonius Lucillus Macer Rufinianus also served in several positions as curator, two of which followed immediately after his praetorship. First, he became curator rei publicae of Suessa, a city in Campania. For his second curatorship both Tusculum in Latium as Puteoli in Campania near Naples are suggested. ${ }^{33}$ Either way, both positions were carried out in Italic cities. A post as legatus and simultaneously as deputy of the governor (vice proconsulis) brought him to Africa, where he would return later in his career, and consecutively led straight to his suffect consulship. These positions can be dated around 225/230, during the reign of Severus Alexander, at about the same time Caesonius' father was comes of this emperor.

Shortly after his consulship, the curator alvei Tiberis et cloacarum urbis became his first consular office. His next job as curator aquarum et Miniciae, the position which his father had also fulfilled, can be dated during the last years of Severus Alexander's reign, between 230 and 235 . In 238 he was chosen as one of the vigintiviri ex senatus consulto rei publicae curandae, who, by senatorial decree, were to set the empire free from the senators' scourge, Maximinus Thrax. His membership in this committee shows the prestige that he held within the senate. Eventually, the committee of twenty succeeded. All the known members of the vigintiviri of 238 had successful careers. ${ }^{34}$ Caesonius Lucillus Macer Rufinianus was awarded a proconsulship of Africa and returned to this province with which he was already familiar. It must have been about ten to fifteen years after his position as legatus and vice proconsulis, probably not before $240 / 241$, considering his participation in meetings of the fratres Arvales in 239 and even in January $240 .{ }^{35}$ Both the Historia Augusta and Zosimus mention the usurpation of a Sabinianus who was acclaimed emperor in Carthage in 240 and was struck down at the end of the year by the governor of Mauretania Caesariensis. ${ }^{36}$ Caesonius may have been sent there to restore order in the province, which would mean that the emperor Gordianus III and his advisers put great trust in him. However, this is merely a conjecture.

That Caesonius concluded his career with a position as praefectus urbi and a judicial task as deputy of the emperor himself (electus ad cognoscendas vice Caesaris cognitiones), also implies that he enjoyed

${ }^{33}$ About the problem, see $P I R^{2} \mathrm{C} 209$ and also Thomasson (1996), 90.

${ }^{34}$ See Dietz (1980), 326-340.

${ }^{35}$ CIL 6.37165 (Roma); Thomasson (1996), 90, note 137.

${ }^{36}$ HA, Vita Gord. 23, 4; Zosimus 1, 17, 1. 
imperial trust. Unfortunately, these last two offices cannot be dated more precisely than with a terminus ante quem of 254 . So, although it is likely that they were also held during the reign of Gordianus III, as is suggested in $P I R$, they could also have been carried out under Philippus Arabs, Decius, Trebonianus Gallus, Aemilius Aemilianus or even Valerianus. It is also unclear whether the two positions were carried out simultaneously or consecutively. ${ }^{37} \mathrm{~A}$ second consulship might have been expected, but Caesonius may have died before he could have been appointed. At any rate, Caesonius Lucillus Macer Rufinianus proved to be one of the more important senators during the first half of the third century, considered loyal by several emperors.

The next generation of the Caesonii was represented by Lucius Caesonius Ovinius Manlius Rufinianus Bassus. ${ }^{38} \mathrm{He}$ was the son of the abovementioned Caesonius and a woman who probably descended from the gens Ovinia, which was important in the third century as well. ${ }^{39}$ His career can be reconstructed from an honorary inscription from Aversa. ${ }^{40}$

He must have been born during the reign of Severus Alexander between 225 and 230, and served in his first position about 240/245 under

${ }^{37}$ Peachin (1996), 114, deals with the problem of dating these positions. He locates Caesonius as vice Caesaris in Rome between 242 and 244, when Gordianus III was conducting his expeditio Orientalis, and thinks this position was prior to the prefecture of the city. He suggests that Caesonius laid down his position as judge when Philippus returned to Rome and that he was then named praefectus urbi, circa 246 . However, Peachin admits that the epigraphic evidence supplies no precision in this regard.

${ }^{38}$ PIR $^{2}$ C 212; PIR ${ }^{2}$ O 186; PLRE I, Bassus 18. See also Christol (1986), 158-176; Thomasson (1996), 93-94, no. 130.

39 According to Settipani (2000), 351, this Caesonius was married to an (Ovinia), who was probably the sister of (L. Ovinius) Pacatianus, who was in his turn married with Cornelia Optata A[quilia?] Flavia ..., the sister of Cn. Cornelius Paternus, consul ordinarius 233. Settipani suggests that L. Ovinius Rusticus Cornelianus, consul suffectus in the middle of the third century, and Ovinius Pacatianus, praefectus urbi 276, may have been their children, and that an Ovinius Iulius Aquilus (?) Nonius Paternus, consul ordinarius 267 ?, consul II ordinarius 279 , praefectus urbi 281 , may have been their grandson. However, he admits that there are too many uncertainties about the Ovinii to construct a stemma. That is why this family has not been included in the list of senatorial elite families discussed here.

$40 A E$ 1964, 223 (Aversa, Italy). He is also known from three other inscriptions (CIL 10.1687 = ILS 1206 (Puteoli, Italy); AE 1945, 21 (Roma); AE 1968, 109 (Fundi, Italy), which add little to our knowledge of his career. According to Christol (1986), 167176 , they refer to the homonymic son of the consul suffectus circa 260. This theory, however, has not been adopted by many scholars. See Leunissen (1989), 202, note 318, and Thomasson (1996), 93, note 137. Even if Christol's assumption is correct, this would only point to another successful generation of the Caesonii within the third century, and would support my argument. 
Gordianus III or Philippus Arabs. Like his grandfather he started his career as triumvir capitalis. Next, he became sevir turmae deducendae (equitum Romanorum), commander of one of the six squadrons (turmae) of equites and responsible for organizing games, which involved great financial responsibility. As a patrician, the next steps in his career were quaestor candidatus and praetor candidatus.

His praetorian career was short. Two stints as curator rei publicae led him directly to the consulate. His first curatorship was carried out in Beneventum in the southern part of Italy and the second one in Lavinium in Latium led him to a city where his grandfather may also have served as curator. He held a consulship around 260, probably as consul suffectus. ${ }^{41}$ At that point his career had survived the many upheavals of imperial power during the 250 s.

His consular career started with a position as curator alvei Tiberis et cloacarum sacrae urbis, following after both his father and his grandfather. He held several positions in Africa, a province he may have known from accompanying his father during his proconsulship. However, this may have interfered with the start of his own cursus honorum. This Caesonius was legatus of Carthage, curator of the Colonia Carthaginensium and finally proconsul Africae for three years in a row. The three African offices are mentioned in succession on his career inscription, but it is doubtful whether they were actually fulfilled consecutively. It has been suggested by both Eck and Christol that the positions of legatus and curator belonged to the praetorian part of his career. ${ }^{42}$ The functions may have been clustered in the inscription because they were all fulfilled in the same area. The proconsulship of Africa, dated around 275 under Aurelianus and/or Tacitus, did not mean that this man's career ended. On the contrary, the emperor Probus chose him to chair the iudicium magnum, probably a court of appeal at Rome. After this, he carried out some other judicial functions under Probus. He was appointed judge (iudex) as deputy of the emperor himself (vice Caesaris) in cases involving the imperial treasury (fiscus) and private individuals, and cases between private persons themselves. ${ }^{43}$ At first, he carried out this office in Rome, probably between 276 and 281, and later, presumably during the last years of

${ }^{41}$ It has been suggested that he was identical with the Bassus, who was consul ordinarius in 259. See Christol (1986), 100-101.

${ }^{42}$ RE Suppl. 14, 82; Christol (1986), 163-164.

43 It is unclear whether this position was first exercised inter fiscum et privatos and later only (item) inter privatos, or whether the categories did not change. See Christol (1986), 166. 
the reign of Probus (281/282), also in Africa. The title comes Augustorum duorum was probably bestowed upon him between 283 and 285 , when Carus and Carinus or Carinus and Numerianus were joint emperors.

Two more offices are mentioned in the inscriptions: a second consulship and a position as prefect of the city Rome. The consulship can be dated around 284 and was presumably a suffect one, which was quite unique. After AD 104, all the consules iterum had been ordinarii. ${ }^{44} \mathrm{How}$ ever, most of the positions of consules ordinarii from 283 to 285 were held by the emperors themselves, so there was hardly any space for nonimperial consules ordinarii in those years, which may explain this uncommon situation. The consulship may have coincided with the position of praefectus urbi. It is striking that this Caesonius is not mentioned in the list of city prefects of the Chronographer of 354 . Scholars usually explain this by suggesting that Caesonius was not praefectus of Rome at the first of January, but was appointed in the middle of a year to replace someone else. ${ }^{45}$ The exact year in which he performed this function is uncertain, but it was probably around 285, during or just before the start of the reign of Diocletian. According to the inscription, Caesonius was also salius Palatinus, pontifex maior and pontifex dei Solis. Only the last priestly office can be dated, although not precisely, since this office only came into use under Aurelianus in 274.

Another function is mentioned only fragmentary in another inscription: $\operatorname{pr}\left[. .\right.$. ]ones tracto Piceno. ${ }^{46}$ Unfortunately, this function cannot be defined with certainty. Suggested solutions are praefectus adversus latrones (against brigands), praefectus annones (sic) (responsible for the corn crop) and praefectus ad tirones (to select recruits). ${ }^{47}$ Besides the fact that the function cannot be determined, it is also problematic that the position within the career cannot be established, since in this inscription the functions seem not to be in chronological order.

A Caesonius Bassus was consul ordinarius in 317. He was probably the son or rather the grandson of Caesonius Ovinius Manlius Rufinianus Bassus. At the end of the third century, the Caesonii became connected to the Anicii, another third-century senatorial elite gens (see below) probably through nuptial bonds. ${ }^{48}$

\footnotetext{
${ }^{44}$ See RE Suppl. 14, 82.

${ }^{45}$ See under $P I R^{2} \mathrm{O} 186$.

${ }^{46} A E$ 1968, 109 (Fundi, Italy).

47 See $R E$ Suppl. 14, 83, by Eck, who prefers the solution suggested by Barbieri of pr[aefectus ad tir]ones.

${ }_{48}$ On Caesonius Bassus, consul in 317, see PLRE I, Bassus 12. According to Jacques
} 


\section{Observations on the Careers and Position of the Caesonii in the Third Century}

Within a century the Caesonii seem to have developed from a rather ordinary senatorial, perhaps originally even equestrian, family into a patrician clan whose members had flourishing careers under many emperors of the third century. The family does not seem to have suffered from the numerous changes of imperial power which appeared especially after $\mathrm{AD} 238$. Quite the contrary. The most impressive appointments within the careers of the Caesonii can be dated after that critical year.

Many similarities emerge between the careers of the three Caesonii. Caesonius Lucillus Macer Rufinianus and his son carried out both their quaestorship and their praetorship as candidati of the emperor. This demonstrates imperial favor as well as their patrician status. Typical of a patrician career is also the relatively low number of offices between the praetorship and the consulship within their careers.

The number of positions, mainly curatorships, in which the Caesonii served in Italy is considerable. The position of curator aquarum, the prefecture of Rome, and possibly also the curatorship of Lavinium, were held by two of them. The post of curator alvei Tiberis even appears in all of their careers. In addition to Italy, Africa was a region in which all of them were active. All three of them reached the high post of proconsul of Africa. In this way the emperors took a certain risk by enabling the family to build up a social network in Africa. The risk of usurpation grew when a family had connections in a certain area and could lead to situations comparable to the seizure of power by the Gordiani in the years 238 to 244 . Their knowledge of the province may have outweighed precautionary measures against usurpation.

In any case, emperors' confidence in the Caesonii was not misplaced: none of them abused their power. On the other hand, after 238, military commanders, not senators, presented the greatest threat to the imperial throne. Military experience, military power and social networks among military officers became sources of power from 240 onward. Those were exactly the qualities that the Caesonii lacked. The positions they held mainly gave them experience in the administrative, financial and legal

\footnotetext{
(1986), 168, Bassus' consular colleague Ovinius Gallicanus may have been a relative. The names of M. Iunius Caesonius Nicomachus Anicius Faustus Paulinus, praetor urbanus 321, and Amnius Manius Caesonius Nicomachus Anicius Paulinus, consul 334, praefectus urbi 334-335, support the assumption that the Caesonii and Anicii became connected in the fourth century. See Settipani (2000), 347-348.
} 
spheres, but hardly any knowledge of the military, and some offices involved more honor than actual power.

Two specific events bolstered the position of the Caesonii between Marcus Aurelius and Diocletian. First, Caesonius Macer Rufinianus' support for Septimius Severus against Clodius Albinus brought the family consular and patrician status and put them on the map as an important senatorial elite family. Second, Caesonius Lucillus Macer Rufinianus' involvement among the vigintiviri in 238 enabled them to maintain their position during a chaotic period and to rise to the highest possible positions within a senatorial career and some intriguing special tasks in direct service to the emperors. Throughout the rest of this period of about a hundred years, the Caesonii seem to have kept low profile, remaining loyal to most emperors, but never so bound to one emperor in particular that his death would cause danger to them. In this way, they were able to survive the chaos and transformations of the third century crises. Establishing relations with other senatorial elite families strengthened the position of the Caesonii even further and enabled them to remain important after 284 as well.

\section{The Senatorial Elite Families-Main Observations}

As has been stated before, the evidence for the careers of the Caesonii is uniquely extensive for the third century. Of the remaining families, of whom members were prominent in key functions, only fragmentary evidence survives. However, the evidence of developments and relations in similarly elite families largely parallels the Caesonian careers and position. By combining the results of the complete record of the gens Caesonii with the fragmentary evidence on these other families, I have been able both to expand my theory of such senatorial elite families' continuining hold on positions which involved status and power and to define a senatorial nucleus within the third-century senatorial elite. A more detailed prosopographical account appears at the end of this chapter. Here, the main observations are summarized and illustrated with examples from this prosopography.

The first observation is that the analyzed families were particularly bound to Italy. A considerable number of these gentes seems, like the Caesonii, to have had Italic roots. In eight cases (44\%), Italic origin seems most likely, while in seven other cases (39\%) Italy has been suggested as a possible homeland (see Table 2.2). 
Table 2.2 Geographic origin of the selected families

\begin{tabular}{ll} 
Gens & Geographic origin \\
\hline Acilii & Probably Italy \\
Anicii & Africa (Uzappa) or Italy (Praeneste) \\
Bruttii & Italy (Volcei, Lucania) \\
Caesonii & Italy (Regio I, Antium?) \\
Catii & Dalmatia, Gallia or N-Italy \\
Claudii Pompeiani & Syria (Antiocheia ad Orontem) \\
Claudii Severi & Galatia (Pompeiopolis) \\
Egnatii & Bithynia, Numidia or Italy (Etruria) \\
Fulvii Aemiliani & Italy \\
Hedii Lolliani & Italy (Liguria) \\
Marii & Africa or Italy \\
Nummii & N-Italy (Brixia) or S-Italy (Beneventum) \\
Pollieni & Italy \\
Pomponii & Italy \\
Postumii & Numidia \\
Valerii & Italy (Lavinium, Latium) \\
Vettii & Africa, Gallia Narbonensis or Italy \\
Virii & Asia Minor or N-Italy \\
\hline
\end{tabular}

Such suggestions are based mostly on funerary inscriptions, epigraphic evidence pointing at regional landownership, or inscriptions honoring patroni or commemorating a person's benefactions to a city. As stressed before, they are rarely confirmed by other evidence. Obviously it should be noted here that establishing a senatorial family's geographic origin is problematic. ${ }^{49}$ Provincial newcomers in the senate were expected to invest capital (i.e. acquire landed property) in Italy, which in some cases causes trouble in determining a family's origin. ${ }^{50}$ Talbert, however, suggests that this requirement may soon have lapsed, since 'the amount of surviving evidence for ownership of Italian property by provincial senators is puzzlingly small. ${ }^{51} \mathrm{He}$ adds that there must have been many

49 Cf. Hopkins and Burton in Hopkins (1983), 144, on Hammond (1957): 'His precise conclusions depend on the reliability of the attributions of origin, which are often debatable $[\ldots$.$] ?$

50 From Plinius, Epistulae 6, 19, we learn that Traianus had ordered candidates for public office to invest a third of their capital in Italian land. HA, Vita Marc. 11, 8, reports that Marcus Aurelius demanded from senators of non-Italian origin that they invested one quarter of their capital in Italy. On the financial obligations of senators, see also Talbert (1984), 54-66.

51 Talbert (1984), 56. Cf. Hopkins and Burton in Hopkins (1983), 189, note 93, who argue that 'the reduction in the required proportion implies that it was difficult to secure compliance.' 
provincial senators who re-moved altogether to Italy and points out the remark of Paulus who 'makes the striking point that a senator removed from the order is restored to his country of origin only by special request. ${ }^{52}$ Krieckhaus has demonstrated for the first and second centuries $\mathrm{AD}$ that senatorial families, even though they entered a new environment in Rome, were clearly still very much attached to their old patriae economically, socially and emotionally. ${ }^{53}$ Krieckhaus' study has confirmed the earlier view of Eck, who has also included the third century AD in his examination, and argued against underestimating the continuining strength of ties between senators and their old patriae. ${ }^{54}$ That the eighteen families in my analysis were so strongly connected in Italy is therefore all the more significant. Apparently, they were so well-integrated in Italy and Rome that their attachment to the Italic peninsula equalled or even exceeded their connection with their patria. Therefore, with the majority of these families it is difficult to specify Italian or provincial origins. Only in three of the eighteen cases (17\%) can Italic origins be excluded with certainty: the Claudii Pompeiani, the Claudii Severi and the Postumii. By the third century, however, these gentes must have been fully integrated into Rome as well, as nuptial bonds had connected these families with the emperors Marcus Aurelius and Pertinax. ${ }^{55}$ Thus, it seems safe to argue that all the analyzed families either had Italic roots or were otherwise strongly bound to Italy and Rome by the third century. Furthermore, only a very small minority of the analyzed gentes show obvious signs of eastern origins. This is striking, since from the second century onward the number of easterners rose steadily within the senate. ${ }^{56}$

52 Talbert (1984), 56, referring to Digesta 50, 1, 22, 4.

${ }^{53}$ Krieckhaus (2006).

54 Eck (1980), 318. A different view was expressed by Syme in the posthumously edited and published Syme (1999), 4: 'A generation or two of service would loosen the links that bound a family to the town or province of its origin.' Cf. Krieckhaus (2006), 7. See also id., 15, where Krieckhaus argues that from the Severan era onwards the concepts patria and origo became exchangeable in the ancient legal sources.

${ }^{55}$ Both Claudius Pompeianus and Claudius Severus (consules II ordinarii 173) were married to daughters of Marcus Aurelius. The Postumii probably descended from Flavius Claudius Sulpicianus, father-in-law of Pertinax.

56 Halfmann (1979) See also Hammond (1957), who argues that in AD 69-79, $17 \%$ of known senators whose origins were known were of provincial origin, chiefly $(70 \%)$ from the western provinces, and that $\mathrm{AD} 193-212,57 \%$ of all known senators came from the provinces; $58 \%$ of them were from eastern provinces. Cf. Hopkins and Burton in Hopkins (1983), 144-145. 
Besides these strong ties with Italy, analysis demonstrates that the majority of the eighteen families reached patrician status at some point. This status is not always mentioned explicitly, but in several cases it can be deduced from the fact that a person was an imperial candidatus or triumvir monetalis. ${ }^{57}$ Six of the examined gentes $(33 \%)$ certainly were patrician; three of them had obtained this status well before 193, and the other three were accepted into the patriciate in the course of the third century. Another third may have had patrician status. Most of the families which entered the patriciate between AD 193 and 284 had already been appointed into (ordinary) consulates, proconsulships and the city prefecture well before they reached patrician rank.

Table 2.3 Patrician status of the selected families

\begin{tabular}{ll} 
Gens & Patrician status \\
\hline Acilii & From 1st century AD \\
Anicii & From ca. 230/250 \\
Bruttii & Under Antoninus Pius (ca. 160) \\
Caesonii & Under Caracalla (ca. 212/ 217) \\
Catii & No indications \\
Claudii Pompeiani & Possibly before 228 \\
Claudii Severi & No indications \\
Egnatii & No indications \\
Fulvii Aemiliani & Possibly under Marcus Aurelius (ca. 169) \\
Hedii Lolliani & Ca. 170/184 \\
Marii & No indications \\
Nummii & Possibly ca. 191/199 \\
Pollieni & No indications \\
Pomponii & No indications \\
Postumii & Possibly before 272 \\
Valerii & Possibly since the Republican period \\
Vettii & Ca. 200 or 220/225 \\
Virii & Possibly ca. 240/250 \\
\hline
\end{tabular}

For the remaining six families $(33 \%)$ there are no indications that they were accepted into the patriciate (see Table 2.3). They were either no longer accepted into the patriciate, or the explicit mention of patrician status or reference to it in inscriptions no longer necessarily signified elevated status. There are at least some indications for a certain devaluation of patrician status among the senatorial elite in the course of the

57 Christol (1986), 61-62. 
third century here. However, as said, the majority of the analyzed families seems to have reached patrician status at some point.

This group with strong connections with the Italic peninsula and a relatively high percentage of patricians thus appears regularly on the list of consuls, proconsuls, and city prefects between 193 and 284. In the case of the Caesonii we could furthermore notice a number of similarities within the careers of the members of this gens, for instance that relatively many positions were carried out in Italy and Africa. Moreover, a gradual reduction of positions involving military responsibility and a steady increase of positions in the administrative, financial and legal spheres is traceable within their careers. Unfortunately, many of the careers of the members of the other analyzed gentes have not come down to us completely. Yet, if we look at those parts of their careers known to us, some of these Caesonian features emerge.

Like the Caesonii, the other analyzed senatorial elite families were frequently appointed to positions in Rome and Italy. Also like the Caesonii, they continued to hold positions in Africa, Asia and other regions which were not heavily struck by warfare in the period under discussion, such as Spain and Greece (Achaia). There are some cases in which members of the same gens were repeatedly delegated to the same geographic area, like the Anicii in Africa and Numidia, the Hedii Lolliani in Hispania Citerior, and the Marii in Syria. ${ }^{58}$ Yet there is too little evidence to determine whether this indicates a pattern in third-century appointment policies. It can be noted however that the prosopographic and administrative continuity in these regions corresponds with Witschel's findings: in his study on the effects of third-century crises in the Roman West, based mainly on archaeological and epigraphic evidence, he finds economic continuity in these areas. ${ }^{59}$ Appointments of the analyzed senatorial elites in regions which suffered from repeated invasions and enduring war-

${ }^{58}$ Anicius Faustus was legatus in Numidia in 197-201. His descendant Cocceius Anicius Faustus Flavianus was curator in Cirta (Numidia) in 251, and then in the 26os Cocceius Anicius Faustus Paulinus was proconsul Africae. Hedius Rufus Lollianus Gentianus was tribunus militum and later governor and censitor in Hispania Citerior, in the late second century. His son (Hedius) Lollianus Plautius Avitus was iuridicus in northern Spain and legatus legionis in Hispania Citerior, probably early third century. Marius Perpetuus was tribunus legionis in Syria and later legatus legionis in Syria Coele early third century. His brother Marius Maximus became governor of the province of Syria Coele under Septimius Severus as well.

59 Especially in North Africa, Witschel (2004), 267-269, observes a 'conservative urban culture' and 'stagnation at a high level without longterm negative effects'. Cf. id. (1999). 
fare, such as the provinces of Moesia, Dacia, Germania and Syria, were largely restricted to the early third century and became very rare from 240 onwards.

Concurrently, the type of positions held by members of these gentes seems gradually to have changed: the evidence points to an increasing tendency towards selecting these senatorial elite members for civiladministrative, financial and legal offices, especially in the relatively peaceful areas mentioned above. These senators are frequently attested as curator, corrector, iudex (vice sacra), iuridicus, and censitor. Their social pre-eminence, wealth and education made members of the senatorial elite particularly suitable for these regulatory and adjudicatory posts. ${ }^{60}$ Yet, as has been noted, after about 240 they are no longer attested as governors of provinces in which legions were stationed. ${ }^{61}$ These positions went increasingly to equestrian men with abundant military experience, as will be discussed in Chapter 3. Some examples from the analysis illustrate this development: Anicius Faustus was governor of Numidia and Moesia Superior under Septimius Severus. His son Anicius Faustus Paulinus governed Moesia Inferior under Severus Alexander. Yet, from the next generation of Anicii no one was appointed as provincial governor. Cocceius Anicius Faustus Flavianus is only known to have been curator rei publicae in Cirta (Numidia) in 251. Catius Celer was the last member of the Catii known to us who held a provincial governorship, in Moesia Superior in 242. The Egnatii, who were governors of provinces with legions under Septimius Severus (Egnatius Victor in Pannonia Superior), and still under Severus Alexander (Egnatius Victor Marinianus in Arabia and Moesia Superior, and perhaps Egnatius Victor Lollianus in Pannonia Inferior) are not attested as governors of militarily relevant provinces after 235. The same can be said about the Pollieni:

${ }^{60}$ The prime function of curatores (rei publicae) was to investigate and supervise, on a short-term basis, the finances of individual civic communities; in the provinces they could supplement the powers of provincial governors. Correctores also fulfilled regulatory and adjudicatory duties, but they possessed imperium and their powers were more wide-ranging than those of curatores. Iudices were private persons appointed to conduct hearings. In the Late Empire the use of the term became much wider: any official with jurisdiction or administrative power was so called (cf. Cod. Iust. 3, 1, 14, 1). Iuridici were officials of praetorian rank who performed judicial functions in civil cases in Italy: they were appointed by the emperor and assigned to particular districts. A censitor was a tax officer. See OCD, s.v. corrector; curator; curator rei publicae; iudex; and iuridicus. On the curatores in Rome, see also Bruun (2006).

${ }^{61}$ Thus this process seems to have started well before the reigns of Valerianus and Gallienus. Pace Lo Cascio (2005), 160. 
Pollienus Auspex minor governed Hispania Tarraconensis, Moesia Inferior and Britannia probably under Septimius Severus or Severus Alexander; Iulius Pollienus Auspex was legatus of Numidia between 212 and 222. Pollenius Armenius Peregrinus, a member of the next generation, was proconsul of Lycia et Pamphylia, a region in which no legion was stationed, circa 243. Even Postumius Varus, who held a military position as legatus legionis in Britannia shortly before 250, is not attested as governor of a militarily relevant province thereafter, and neither are his relatives. An exception to the rule seems to have been Virius Lupus, who is attested as praeses of Arabia and Syria Coele between 259 and 270. The use of the term praeses, however, may be significant here, perhaps indicating that he had restricted responsibilities: indeed, he probably held these positions while Odaenathus was basically governing the East, who obviously held most of the military responsibility in that area in those days. ${ }^{62}$ Thus, the senators belonging to the analyzed gentes were increasingly deployed in those parts of the Empire that were not heavily struck by repeated invasions and enduring warfare and that had a traditionally high status. As always these senators were both well qualified to govern these parts of the Empire and were acceptable to local aristocracies in those relatively rich, developed areas. In this way, they were still appointed to positions which were prestigious, but which did not involve too much actual military power.

\subsection{Defining a Nucleus within the Senatorial Elite}

As has been demonstrated by this analysis and discussed in the previous section, the gentes that held a considerable proportion of the (ordinary) consulates, proconsulships in Africa and Asia and city prefectures in Rome between AD 193 and 284 had several points in common: (a) they constituted a group with a relatively high percentage of patricians, which (b) was strongly connected to the Italic peninsula and the city of Rome, and which (c) was, especially when third-century crises were coming to a head from 240 until 284 , particularly mobilized in the non-military sphere and in geographical areas which were not struck by long-term crises. Regularly holding the most prestigious consular positions of the senatorial cursus honorum, this group of families can obviously be con-

62 On Virius Lupus in the East under Odaenathus, see Hartmann (2001), 192, although he does not go into more detail on Virius Lupus' activities. 
sidered a significant stratum within the senatorial elite. They managed to maintain or increase their power and status during a substantial proportion of the period under discussion, thus forming a nucleus within the senatorial elite (see Figure 2.1).

Despite, or perhaps due to, the gradual decline of military responsibility, these families evidently strived for continuation of membership in this senatorial nucleus: they took strategic measures to ensure intergenerational participation. They established ties with each other through intermarriage, and adoption was employed to compensate for cases where no (male) children survived into adulthood. In this way, alliances were created between families and property, wealth and status was transmitted smoothly. Moreover, with such strategic alliances the elite families guaranteed cultural homogeneity among themselves, avoiding largescale intrusions of 'new' generations who-in their eyes-did not have the appropriate paideia. As discussed above, the Caesonii were connected to the gens Ovinia through nuptial bonds, and they apparently established relations with the Anicii at the end of the third century as well, as the nomenclature of fourth-century members of the gens suggests: Iunius Caesonius Nicomachus Anicius Faustus Paulinus and Amnius Manius Caesonius Nicomachus Anicius Paulinus. ${ }^{63}$ The Anicii may also have maintained relations with the Hedii. ${ }^{64}$ As it seems, the third-century Postumii descended from Postumius Festus, consul suffectus in 160. His daughter married Flavius Titianus, grandson of an eques who had been governor of Egypt under Hadrianus and son of Flavius Claudius Sulpicianus. The latter's daughter married Pertinax and thus became empress in $193 .{ }^{65}$ Valerius Claudius Acilius Priscillianus Maximus' name indicates that the Valerii united with the Acilii at some point in the third century. When he was consul iterum in 256, his colleague Acilius Glabrio apparently was a relative. ${ }^{66}$ Suggestions that the gens Fulvia Aemiliana was related to the gens Bruttia have been made, based on the nomenclature of the consul II ordinarius in 180, L. Fulvius ... C. Bruttius Praesens. ${ }^{67}$ An Egnatius Proculus who held a suffect consulship at an uncertain date seems to have been the son-in-law of Marius Perpetuus, consul

\footnotetext{
63 See Settipani (2000), 347-348.

64 See PLRE I, Paulinus 16; Settipani (2000), 406-407.

65 See Settipani (2000), 373, for a stemma.

66 See Settipani (2000), 227-228 for hypotheses on the alliance.

67 Dietz (1980), 161-163.
} 
ordinarius $237 .{ }^{68}$ The Egnatii Proculi probably belonged to a separate branch, but seem to have been related to the Egnatii Victores. That intensifying relations with other gentes through nuptial bonds and adoption could have far-reaching results is demonstrated by the example of these Egnatii and the Hedii Lolliani. The sister of the Hedii Lolliani who where consules ordinarii in 209 and 211 married one of the Egnatii (Egnatius Victor, consul suffectus before 207). ${ }^{69}$ Their daughter, (Egnatia) Mariniana married the future emperor Publius Licinius Valerianus and gave birth to the future emperor Publius Licinius Egnatius Gallienus. Although the name Lollianus thus disappears from the consular fasti after 225, the family merged with the Egnatii and later with the Licinii. In this way, the family remained important, though less prominent, until Gallienus was killed in 268 and probably took most of his relatives down with him. The example demonstrates not only the positive results of strategic familial alliances, but also the fact that they were still no guarantee for continuity.

While the prospects for social mobility gradually increased from the second century onward and more and more homines novi entered the ordo senatorius, the possibilities of penetrating this senatorial inner circle must have been severely restricted. In his book on the urban elites of third-century Roman Egypt, Tacoma states that local elites, as it was usually thought,

consisted of a limited number of families that stayed in power for generations on end. They closely guarded their privileged position. [...] As a consequence of the fact that children inherited the wealth and power of their parents and married with children of families of similar wealth, these families formed a close group, with little room for outsiders. ${ }^{70}$

Although Tacoma stresses that continuity for more than two generations was likely the exception rather than the rule for the Egyptian urban elites, he observes that some families in Egypt remained part of the elite for many generations. Tacoma argues that the position of the urban elites in third-century Egypt was fragile and introduces the concept of 'cyclical mobility', which implies that if elites failed to replace themselves, a sub-elite which presumably strove for elite status stood

${ }^{68}$ Or, more unlikely, he was son-in-law of the Marius Perpetuus who was consul suffectus circa 203. On this matter, see PIR ${ }^{2}$ E 31; Dietz (1980) 189; Settipani (2000), 399.

${ }^{69}$ Q. (Hedius) Lollianus Plautius Avitus was consul ordinarius in 209 and (Hedius) Terentius Gentianus in 211.

70 Tacoma (2006), 231. 
ready to fill the vacancies. ${ }^{71}$ This concept of elite circulation seems also to have been applicable to the central senatorial elite dealt with in this chapter: obviously, some families remained part of the senatorial nucleus for many generations, so there seems to have been intergenerational continuity. Although this continuity was never guaranteed, there were ways to enhance the chances. As the capacity of the third-century urban elites in Egypt to remain in power should not be underestimated, as Tacoma argues, neither should the capacity of central elite families who belonged to the senatorial inner circle. As demonstrated above, strategic alliances through marriage and adoption were of paramount importance and could even for a generation create the impression that a child continued both lines, although eventually continuity remained reserved for the paternal branch. A (possibly fictitious) anecdote of the emperor Valerianus, visiting public baths with his general staff, shows how elites would manipulate adoption strategically. Through Ulpius Crinitus, who allegedly was the general in command of the Illyrian and Thracian frontier, the author of the Historia Augusta says:

According to the custom of our ancestors, Valerian Augustus,-a custom which my own family had held particularly dear,-men of the highest birth have always chosen the most courageous to be their sons, in order that those families which either were dying out or had lost their offspring by marriage might gain luster from the fertility of a borrowed stock. ${ }^{72}$

In the end, it was membership in the senatorial nucleus, not the history of a person's family that was important. Tacoma's statements that 'elite marriages were endogamous in a social and geographical respect' and 'isogamous in that marriages occurred between people of roughly equal status' also applies for the senatorial elite families examined here. ${ }^{73}$

Yet, if despite all these possibilities for strategic alliances the senatorial inner circle failed to regenerate itself, opportunities permitted sub-elite to penetrate the senatorial nucleus. It is noteworthy that more than two-third $(67 \%)$ of the analyzed gentes who eventually belonged to the senatorial nucleus defined here reached consular rank and thus joined the central senatorial elite during the reigns of Marcus Aurelius ( $28 \%)$ or Septimius Severus (39\%) (see Table 2.4).

\footnotetext{
71 Tacoma (2006), 156-160; 232.

72 HA, Vita Aurel. 14, 5.

73 Tacoma (2006), 242-243.
} 
Table 2.4 Years in which the selected families reached consular rank

\begin{tabular}{ll} 
Gens & Consular from \\
\hline Acilii & AD 24 (Tiberius) \\
Anicii & AD 198 (Septimius Severus) \\
Bruttii & AD 118/119 (Hadrianus) \\
Caesonii & AD 197/198 (Septimius Severus) \\
Catii & 2nd century AD (Antoninus Pius?) \\
Claudii Pompeiani & Circa AD 167 (Marcus Aurelius) \\
Claudii Severi & AD 112 (Traianus) \\
Egnatii & AD 207 (Septimius Severus) \\
Fulvii Aemiliani & AD 155/160 (Marcus Aurelius) \\
Hedii Lolliani & AD 114 (Traianus) \\
Marii & AD 199/200 (Septimius Severus) \\
Nummii & AD 206 (Septimius Severus) \\
Pollieni & AD 170/175 (Marcus Aurelius) \\
Pomponii & AD 94 (Domitianus) \\
Postumii & AD 160 (Marcus Aurelius) \\
Valerii & 509 BC (Republican era) \\
Vettii & AD 175/176 (Marcus Aurelius) \\
Virii & AD 196/197 (Septimius Severus) \\
\hline
\end{tabular}

The widespread pestilences and the many wars which afflicted the Empire under Marcus Aurelius, and the Parthian wars, but especially the civil wars and the resulting senatorial executions and confiscations under Septimius Severus may have prevented the central senatorial elite in general and the senatorial nucleus in particular to reproduce. ${ }^{74}$ This would explain the relatively large group of consular newcomers during those reigns: there was a need for renewal. Ironically, some of those newcomers were successful homines novi, who seem to have been rewarded for their loyalty in military crises, as was the case with Claudius Pompeianus, general under Marcus Aurelius, and Marius Maximus and Virius Lupus, generals who were mobilized by Septimius Severus during his early reign (see Chapter 4).

${ }^{74}$ On the wars and pestilence under Marcus Aurelius, see, for instance, Eutropius, Breviarium $8,12-14$; on the impact of the Antonine plague and its consequences for demographic developments, see, for instance, Duncan-Jones (1996); Bagnall (2000); Scheidel (2002); Bruun (2003); on the executions and confiscations among senators under Septimius Severus, see Dio 76, 8, 4, pp. 214-215; HA, Vita Sev. 12-13; Birley (1988), 127-128. Cf. Hahn-Leunissen (1990), 68 and 61, summarizing risks to which senators were exposed as follows: a violent end by imperial mandate, death in battle, death as a result of disease contracted while on campaign, and exile. Clearly, the number of risks for senators decreased in the third century when not only did they rarely participate in campaigns, but increasing imperial absence in Rome helped them escape emperors' attention. 
The question of how long a family generally served within the senatorial nucleus cannot be answered easily. Some of the families which flourished in the third century claimed descent from Republican gentes, like the Acilii Glabriones et Aviolae and the Valerii Messalae. As noted above, however, by far the largest group obtained consular status during the reigns of Marcus Aurelius or Septimius Severus. At the end of the Severan dynasty or perhaps somewhat later, about mid-third century, almost half of the analyzed gentes disappeared from the consular fasti. Consequently members of those families were no longer qualified to carry out consular top positions. It were not only those families which descended from supporters of Marcus Aurelius and Septimius Severus which disappeared (temporarily) from the senatorial elite after the Severan dynasty had stopped providing emperors. Surely, some of the 'Antonine' and 'Severan' gentes lost their position in the senatorial nucleus when Severan dynasty ended, such as for instance the Claudii Pompeiani, the Claudii Severi and the Marii. Yet the positions of other gentes which had obtained consular status well before the second half of the second century AD, such as the Acilii and the Bruttii, also seem to have (temporarily) declined. ${ }^{75}$ Although it must be noted that (temporary) absence from the sources does not necessarily imply social decline, the phenomenon that some families became entirely imperceptible after about 250 indicates that they opted out of politics-either voluntary or involuntary-, especially when members of those families did not reappear in consular positions in the fourth century. In that case, a gens may have continued to be a senatorial family, but should clearly no longer be regarded as belonging to the central senatorial elite, let alone the senatorial nucleus.

At the risk of stating the obvious, I would like to stress once more that the senatorial nucleus defined and discussed in this section must have consisted of more gentes than the eighteen which were included in my analysis. Inevitably, my criteria have obscured some families from view. However, the intention of this analysis is not to paint a complete picture of the senatorial nucleus, but to check the level of continuity in the relationship between status and power by looking at some manifestations thereof and finding where continuities lie.

75 Although it must be admitted that the Acilii seem to have had a revival from the fifth century onwards. 


\section{Senators and Statistics}

The senatorial elite of the first three centuries AD has been analyzed by Hopkins and Burton in $1983 .{ }^{76}$ Based on their intergenerational analysis of senatorial membership and holders of the consulate they rejected both the traditional view that membership of the senate was hereditary and Alföldy's notion of a de facto inheritable consulate under the Antonines. ${ }^{77}$ Their statistical analysis and its conclusions were heavily criticized, particularly by Hahn and Leunissen, who have argued that 'numbers and statistics provide no ready answers to historical questions' as they 'depend upon judicious interpretation. ${ }^{78}$ I agree with them that the conclusions of Hopkins and Burton do not follow from a merely statistical analysis of sample studies and that a supplementary study of individual cases is essential. ${ }^{79}$ Even though this chapter started from a different research question, Hopkins' and Burton's study of inheritance raises important questions for this study; therefore I find it valuable to discuss briefly how the outcome of my prosopographical analysis relates to their results.

Two basic inferences shared by both Hopkins' and Burton's analysis and mine are, first, the distinction between membership in the senatorial order and full active membership in the senate, which involved holding senatorial office, as well as, second, the identification of an elite within the senate consisting of members of consular rank. I have argued one step further in recognizing a nucleus of several families which dominated the senatorial elite, as they provided a substantial share of a number of high consular positions in the third century. ${ }^{80}$ Hopkins and Burton also identified a two-tier system within the senatorial elite, but they distinguished between a small inner-core of ordinary consuls, most of whom had consular origins, and a larger, outer band of suffect consuls, many from non-consular families. From that, they furthermore distinguished a 'grand set' and a 'power set'. Their 'grand set', comprising the patrician and other most noble senators, often sons of consuls, was kept away from

\footnotetext{
${ }^{76}$ Hopkins and Burton in Hopkins (1983), 120-200.

77 Hopkins and Burton in Hopkins (1983), 126-127, contra Alföldy (1976), 288-289, and id. (1977), 84-94.

${ }^{78}$ Hahn and Leunissen (1990), 77. Cf. Duncan-Jones (1984) with some critical notes. See also Burton's response to Hahn and Leunissen: Burton (1995).

${ }^{79}$ Cf. Duncan-Jones (1984), 273, who also criticizes the absence of a summary of the base data in Hopkins' and Burton's study.

${ }^{80}$ Cf. Hahn and Leunissen (1990), who argue that the 'consular aristocracy was such a multifarious and illustrious social grouping', that it is questionable whether they can 'all be painted in exact mathematical strokes'.
} 
military power. According to Hopkins and Burton, some of the senators belonging to this set probably comforted themselves with social influence and with an extravagant social life in Rome, which both expressed and enhanced their status. Their 'power set', on the other hand, consisted of senators who governed the major military provinces and men who served the emperors as commanders of legions. Only a few of them had consular or even senatorial fathers: most of them came from families new to the political elite, and most descended from rich and respectable Italian or provincial gentry. A small minority consisted of social climbers, who made their way up from a less respectable social milieu, usually through military service. ${ }^{81}$ As my prosopographical analysis has demonstrated, both their distinction between a group of ordinary and one of suffect consuls and their division between a grand (status) set and a power set tend to oversimplify matters, at least where the third century is concerned.

Hopkins and Burton also recognize considerable persistence by some senatorial elite families over several generations under the emperors. Likewise, they acknowledge that the senatorial elite living in Rome was small and that most members must have known each other. Their analysis, however, only focuses on paternal descent, and with that they lose track of alternative interrelations within the senatorial nucleus. That is why they did not recognize that a part of the senatorial elite apparently did band together effectively to minimize the risks to their individual and especially their collective status. ${ }^{82}$

Just as the senatorial elite during the Principate was not as weak as Hopkins and Burton present them, so also the distinction between a 'grand set' and a 'power set' within the senatorial elite ceases to exist in the course of the third century, especially from about 240 onward, when senators were apparently largely replaced as military commanders and governors of militarily relevant (frontier) provinces by equites. Furthermore, the relative power exercised by members of the senatorial nucleus in areas such as Italy, Africa and Asia should not be underestimated: the absence of large numbers of military men of relatively high social standing in those regions and the decreasing presence of emperors and imperial relatives in those areas in the third century must have improved their capacity to influence local politics. ${ }^{83}$ Referring to them as a 'grand set', a

${ }^{81}$ On the 'grand set' and 'power set', see Hopkins and Burton in Hopkins (1983), 172173.

${ }^{82}$ Pace Hopkins and Burton in Hopkins (1983), 175.

${ }^{83}$ Mitchell (1993) has demonstrated that military presence in Asia Minor increased in 
mere status set, as Hopkins and Burton did, does not seem therefore to correspond to third-century historical reality. Moreover, what they had to give up in the military sphere of authority, they probably gained in the civil-administrative, legal and financial spheres, as the evidence points at an increasing number of curatores, correctores, iudices and iuridici- that is, ad hoc appointments for which members of the senatorial elite were extremely suitable. Thus it was not only the formal status of the senatorial elite which remained high, for their collective power did not decline as dramatically as has often been argued either.

As to circulation in the senatorial elite: my analysis has shown that opportunities to penetrate the senatorial nucleus evidently increased in periods in which senatorial mortality heightened, such as the reigns of Marcus Aurelius and Septimius Severus. Hopkins' and Burton's additional suggestion of political withdrawal as another catalyst of circulation within the senatorial elite may be true, but cannot be confirmed by individual case studies: the reason why families (temporarily) ceased to be part of the senatorial elite can rarely be recovered. Although Hopkins and Burton detected a remarkable drop in succession rates in the senatorial elite in the first three centuries AD, they have argued that succession rates were significantly higher among high-ranking senators. This assumption seems to be affirmed by my analysis. Whereas the number of provincials within the senatorial order was steadily rising from the later first century onward, and the percentage of members of the senate with provincial origins grew, provincials did not penetrate the senatorial nucleus on a large scale, or, if they did, their attachment to Italy and Rome apparently came to overshadow that of their provincial patria. Based on the notion that provincial newcomers kept the bulk of their property outside Italy and saw their expenses increase immensely while they lived in Rome and participated in political life, Hopkins and Burton argued that many of those men probably preferred to return to their patria after having completed the senatorial cursus honorum: at home, they could derive more power from their senatorial status than in Rome, while an Augustan law kept some priviliges associated with senatorial status for sons of senators and

the third century AD. This military personnel (e.g. beneficiarii at their stationes), however, was not of high social standing and does not seem to have dominated the province. As in other parts of the Empire, they probably concentrated their dwellings, and therefore their influence, mainly around cross roads and imperial property. Furthermore, it should be kept in mind that in Italy senators had always been extremely powerful at the local level. One of many examples is Plinius minor, who owned large properties and was a notable benefactor in his birthplace Comum (mod. Como). 
their descendants in the male line down to the great-grandson. Largescale 'political withdrawal' after one generation may explain why provincials hardly penetrated the senatorial nucleus. ${ }^{84}$ Yet, as this conclusion cannot be drawn from Hopkins' and Burton's analysis or mine, it remains an argumentum ex silentio. ${ }^{85}$ The position of the senatorial nucleus, however, was apparently not weakened by rising provincials.

The Roman senate in the third century $\mathrm{AD}$ may not have been a hereditary status group. ${ }^{86}$ Yet, as my analysis has shown, membership in the senatorial nucleus seems to have been more or less hereditary, since members entered into strategic alliances with each other to increase their chances to remain in this senatorial inner core. Moreover, this group's level of power in specific geographic areas and spheres of authority should not be underrated.

\subsection{Conclusion}

This chapter discussed continuity within the senatorial elite. Beginning with a number of consular positions within central imperial administration, which were principally assigned to senators both before and after the period under discussion and in which senatorial power manifested itself most clearly, I have inventoried a substantial proportion of the senatorial elite which served the emperors at the level of central administration between AD 193 and 284. These lists enabled me to mark out eighteen gentes which apparently dominated the senatorial elite in the period under scrutiny: these gentes provided a substantial percentage of the (ordinary) consuls, proconsuls in Africa and Asia, and city prefects in Rome. A detailed prosopographical analysis has shown similarities in the profiles of these families which collectively constituted (part of) a nucleus within the central senatorial elite, as they were able to maintain or even improve their positions during the period of crises. All families in this senatorial inner circle were strongly attached to Italy, and a considerable proportion of them had or reached patrician status at some point in the third century.

\footnotetext{
${ }^{84}$ Hopkins and Burton in Hopkins (1983), 196.

${ }^{85}$ Hahn and Leunissen (1990), 79-80, consider it unlikely that particularly the sons of consuls who came from provincial families will have withdrawn from political life as they were expected to build up and use their political connections in Rome in the service of their patriae as patroni.

${ }^{86}$ Hopkins and Burton in Hopkins (1983), 136.
} 
The existence of a senatorial (patrician) nucleus was not a novelty. Previous studies have established similar situations in the first and second centuries AD. ${ }^{87}$ Yet a gradual shift in power aspects, as defined by Dahl, occurs: in the course of the third century the senatorial elite by degrees lost its influence in the military sphere to equites. Their scope of power was thus increasingly restricted to civil-administrative, legal and financial positions. The domain in which they exercised power was also limited: they were assigned increasingly to geographical regions which not only experienced few long-term problems such as repeated invasions and enduring warfare, but also kept a traditionally high status within the Empire, for example the provinces of Africa and Asia. Moreover, they were also appointed to functions in Rome and Italy. From the $240 s$ onwards, members of this senatorial nucleus were rarely appointed in provinces occupied by legions. However, the amount of power they exercised inside their assigned areas should not be underestimated: that the emperors sojourned in Rome less frequently than ever before, and focused less attention on relatively peaceful areas such as Africa and Asia, especially after the Severan era, enabled this group to strengthen its position and exercise quite some influence there. Besides, no cabals of military men existed in those regions to compete with the senatorial elite in status and dominate in claiming power. So despite the territorial restriction, the level of control of the senatorial nucleus over those areas not only remained consistent, but it probably even grew.

Although the power of this group was decreasingly founded on actual military power, their other power bases remained intact: their traditionally high social standing, their compactness in size and consequent cohesiveness, and their bonds to Rome and Italy. This group obviously was aware of the advantages of belonging to the senatorial elite in general and the inner circle in particular, as they strove for continuation of their membership by strategically entering into alliances with other senatorial elite families. Senatorial elites were as always very well qualified to govern the relatively peaceful parts of the Empire, which were rich and developed, as they not only remained men of noble birth, but also well-educated and wealthy men. This made them acceptable to local

87 See for instance Eck (1970) and Alföldy (1977). Obviously, having analyzed families which belonged to the senatorial nucleus between AD 193 and 284, the contrast between the first and second centuries and the third century has remained underexposed. However, the aim here was to reconstruct the process of shifts in power and status within the third century. A comparison with previous centuries was beyond the scope of this research. 
elites in the areas which were continually assigned to them. Again, the only change in their status profile was their decreasing military role. By continually appointing those senators at such prestigious top positions, emperors gave them the honors due to them without giving them too much actual (i.e. military) power. In the earlier Principate, emperors had acted likewise towards the patrician nucleus of the senatorial order, and both the emperors as well as the members of elite senatorial families seemed to agree with this policy. The latter maintained their social status without taking too much risk, and the emperors were probably glad that certain mechanisms of the old system did not call for change but continued to function as they had done before. Keeping the senatorial elite families satisfied in this way would also legitimate their position all the more. Yet, as has been noted in Chapter 1, communication of the senators with the third-century emperors became increasingly complicated as the changing background and priorities of the emperors caused that they were no longer on a par with the senatorial elite.

In sum, the events of the third century did not transform Roman society completely: prestigious senatorial top positions remained in the hands of (a nucleus of) the central senatorial elite as before, and were not (permanently) transferred to equites. As always, the possibilities to penetrate this senatorial core group or even to become a member of the senatorial elite were restricted and they do not seem to have been eased by the increasing prospects for social mobility from the second century onwards. Senators who did not belong to the senatorial elite or its inner circle were obviously affected more severely by the crises of the third century, as has been discussed by many scholars. Here, I have sought to demonstrate that along with changes, there was also a certain level of continuity, although chiefly for a restricted group of the senatorial order. However, the gradual disappearance of the coincidence of high social status and the ability to exercise power in the Roman Empire in the third century is undeniable, as will become clear from the next chapter as well. 